\title{
Iranian Male and Female EFL Teachers' Attitudes towards Self-and Peer-Assessment in Descriptive Writing: A Mixed Methods Study
}

\author{
Hanyieh Davatgari Asl ${ }^{1}$, Masoud Zoghi ${ }^{2,}$ Peiman Rahmani ${ }^{3}$ \\ ${ }^{1}$ Assistant Professor, Islamic Azad University of Ahar \\ hdavatgar@ymail.com \\ ${ }^{2}$ Assistant Professor, Islamic Azad University of Ahar \\ dr.m.zoghi@gmail.com \\ ${ }^{3}$ English Language Departments, Islamic Azad University of Ahar \\ payman_rahmani2@yahoo.com(Corresponding Author)
}

\begin{abstract}
The main purpose of this exploratory sequential mixed methods study was to elicit Iranian male and female EFL teachers' attitudes towards self-and peer-assessment in descriptive writing. To reach the research goals of the study, a questionnaire based on Bartlett (2015) and Spencer (2005) models was developed in two various strands. In the qualitative strand, six themes were taken from the administered interviews to predict Iranian male and female EFL teachers' attitudes namely: "cooperation and positivity", "independence", "practice", " strengths and weaknesses". In the quantitative strand, exploratory factor analysis (EFA) was used to validate the recommended themes and to test the participants' attitudes one way-MANOVA was manifested, too. The whole results of the two strands represented the fact that Iranian male and female EFL teachers had positive attitudes towards self-and peer-assessment in descriptive writing, and there was a statistical significant difference between males and females. Additionally, the findings of the research indicated that Bartlett (2015) and Spencer (2005) models were useful in increasing the research participants' knowledge in descriptive writing. Ultimately, these can have implications especially with regard to assessment issues not only EFL language teachers but also for EFL language learners..
\end{abstract}

Keywords: attitude; self-assessment; peer-assessment; descriptive writing; Iranian EFL context

\section{Introduction}

Bearing in mind the expansion of various educational procedures in the field of writing from 1960 to 199 o even further in the review of the literature different approaches of writing as an of example genre-based approach can be observed [1]. Also, in their book titled "Longman Dictionary of Language Teaching and Applied Linguistics", pointed to four modes or genres of writing such as descriptive, narrative, expository, and argumentative. [2]
Among the stated genres of writing, descriptive writing is still considered as the most basic form of writing [3]. In the first view, it is simple for an academic discourse but it is " vital and the best way to lay the foundation of the writer's craft". Moreover, all kinds of writing consist some elements of descriptive writing that cause a reader to see, think, feel, and react[4]. Descriptive writing incorporates a colourful piece of a person, a place, a thing, or an idea using concrete, and also vivid details [5] . By describing a person, a place or an object with graphic or clear details, a writer can create a descriptive scene in the reader's mind [6]. Therefore, each mode of writing activates different types of processes in the mind of the writers and it follows different procedures. 
[7] stated that descriptive writing is appropriate for EFL teachers and junior high school students, especially those who are in grades seven, eight, and nine or ages between "12-17". In teaching descriptive writing, sensory details, such as the sense of sight, sound, smell, taste, and touch, along with figurative language such as simile, personification, metaphor, and also vivid words are some of the components that must be applied [8]. Sensory details are important to create an intense, descriptive image that seems to bring the words on the page to life [9]. Fortunately, along with the development in English language teaching especially writing skill, in general, great changes have been made in English language testing and assessment. To date, many forms of assessment such as self-and peer-assessment techniques have been proposed. Self-assessment is a technique which was derived from theoretical underpinnings of learner autonomy was first proposed by . that it is an input into teaching profession that motivates students to take charge of their own learning and helps them to become independent in the own future learning. Peer-assessment is another technique which was firstly mentioned in Kubany's research in 1957. stated that students can use it to score their peers' works. According to Bartlett, it assists students of all ages in the beginning years of instruction, and helps EFL teachers to provide an interactive environment for them, too. [10]

Hence, owing to increase the tendency of researchers in the ELT towards genre-based approach in writing skill and self and peer assessment in language testing and assessment, the current study attempted to incorporate self-and peer-assessment techniques developed by Henry [11]. new model of self-and peer-assessment as two current forms of testing and assessment procedures in descriptive writing to empower the strength of independence and corporation of the subjects of this study both inside and outside of the classroom [12]

\section{Methodology}

\section{Statement of the Problem and the Research Questions}

Despite the considerable efforts which have been made to improve EFL teachers' knowledge of writing, there are crucial problems which are still needed to be taken into consideration to improve EFL teachers' knowledge of descriptive writing, especially. The two major shortcomings of this study were as following: self-and peer-assessment techniques in writing have been considered qualitatively or quantitatively and it seemed in no studies unified instrument i.e., attitudinal scale to measure Iranian male and female EFL teachers' attitudes towards self-assessment-and peerassessment in descriptive writing, in particular, have been proposed. These deficiencies triggered the researcher to attend to this issue as an exploratory sequential mixed methods research design from social science theoretical lens i.e., a theory that provides a framework from social sciences and guide the nature of the questions asked and answered in a study (Creswell and Clark, 2007, p.47), in two standpoints. To this end, the researcher raised the following questions in two strands: qualitative and quantitative

For the first qualitative strand of this study, the guiding research question is:

RQ NO. 1: What are the Iranian male and female EFL teachers' attitudes towards self-and peer-assessment in descriptive writing?

For the second, quantitative strand of this study, the guiding research questions are:

RQ NO. 2: Do the identified factors/ variables predict Iranian male and female EFL teachers' attitudes towards self-and peer-assessment in descriptive writing?

RQ NO. 3: To what extent, is there a statistically significant difference between Iranian male and female EFL teachers' attitudes towards self-and peer-assessment in descriptive writing in terms of the factors identified?

Objective of the Study

To accomplish the overall purposes of this study, exploratory sequential mixed methods design (ESMMsD), a model proposed by Creswell and Plano Clark (2007) was implemented.

In the first qualitative strand of the study, these purposes were followed:

The first aim of this strand was to encourage and invite purposefully Iranian male and female EFL teachers to take part in a course named "the use of self- and peer-assessment techniques in descriptive writing". The second goal of this strand was to consider the extent of familiarity in which Iranian male and female EFL teachers had about descriptive writing. The third and fourth purposes of this strand were to elicit Iranian male and female EFL teachers' attitudes towards the implementation of self-and peer-assessment techniques in descriptive writing through newly developed personal interview and identify factors which were involved in descriptive writing. The last aim of this strand was to design a five-points Likert scale questionnaire ranged from strongly agree to strongly disagree for Iranian male and female EFL teachers in line with the obtained results of the interviews in the qualitative strand.

In concordance with the aims of the qualitative strand, the general purposes of this follow-up quantitative strand were formed as following:

The first goal was to find out whether there was a statistical significant difference between Iranian male and female EFL teachers' attitudes towards descriptive writing in terms of the identified factors from the developed questionnaire. Another goal was to understand the participants' general attitudes in both strands towards self-and peer-assessment in descriptive writing. The ultimate goal of this strand were to match the results of this strand and the first strand to answer the research questions, and to find scientific solution/s to the recognized research problems in the Problem Statement Section

The Research Design

To accomplish this study purposes, the researcher used exploratory sequential mixed methods design/ESMMsD developed by Creswell and Plano Clark (2007). It involved 
a two-phase project in which the researcher gathered qualitative data first and then followed up quantitative data. The aim of inclusion of the second strand was to explain initial qualitative results.

\section{Strand One: Qualitative}

\section{Settings and Participants}

In the qualitative strand of this study, the researcher selected 40 Iranian EFL teachers including 20 males and 20 females through convenience sampling procedure in seven English language academies in Sanandaj, Iran. Best and Kahan (2006) defined convenience sampling as the number of individual that are accessible in an investigation. The participants of the study were given consent forms to sign and were asked to withdraw at any stages of the research if they liked.

\section{Procedure}

To accomplish the research purposes of this study, the investigator asked the teachers to take part in a training course named "the use of self-and peer-assessment techniques in descriptive writing", for at least three months in the spring of 2019. At the beginning of the course, a short history of different types of assessment such as self-and peer-assessment and also different modes of writing especially descriptive writing were presented. In case of self-assessment and peer-assessment techniques, the researcher provided short explanations, definitions, purposes, characteristics, advantages, disadvantages, and applications of them. In this stage of the course, the selected participants were familiarized with Bartlett's model (2015) of peer-and self- assessment i.e., two stars and a wish (a model in which two positive points were given to the participants' compositions and one helpful suggestion was given to improve their compositions) (see App. C). In the second and third sessions, the teachers were requested to write a composition. After that, the participants were asked to give their compositions to their nearest peers to assess them in the classroom via peer-assessment technique and after returning the compositions the participants were asked to assess their own compositions through self-assessment technique based on the knowledge that they received from the training session, too. After applying Bartlett's model for the first time, the teachers were practically familiarized with Sensory Details, Figurative Language, Vivid Words or SFV model of Spencer (2005) in the fourth sessions. In the first stage of this model strategies of free-writing such as brainstorming and mind mapping were explained. In the second stage of this model "whilst-writing", SFV model was worked out. In this stage a detailed description of descriptive writing elements (e.g., sensory details, figurative language, and vivid words) were elaborated. Suriyanti and Yaacob (2016) sensory details involve five senses such as sight, sound, taste, smell, and touch. They permit the individuals to see the real objects that are being described as if they touch, see, hear, or smell them. Arp and Johnson (2006) figurative language - language using figures of speech (such as hyperbole, simile, metaphor, and personification) is a language that cannot be taken literally (or should not be taken literally only). Richards and Schmidt (ibid) stated that hyperbole is an exaggerated statement, such as I'm so Hungry, I could eat a horse. Richards and Schmidt (2010) and Johanessen (1995) defined simile as an expression in which something is compared to something else by the use of a function word such as like, as, than, similar to, resembles, or seems e.g., Tom eats like a horse or her beauty is like Cinderella's. They also stated that a metaphor is different from a simile. While a simile expresses the two things are similar (e.g., the man is as strong as a lion), a metaphor implies that the two things are equivalent (e.g., the man is a lion or Anny is a flower in my class). Arp and Johnson (2006) personification assists in giving the attributes of a human being to an animal, an object, or a concept (Sylvia makes a mirror speak and think). Johanessen (1995) provided this example, "his pen dances on his book". The word "dance" refers to human characteristic, and the word "pen" is considered a live object. Spencer (2005), Manery (2003) and Johannessen (1995) stated that vivid words are specific words which involve in descriptive writing. A vivid word is a specific modifier, for example, in the sentence "the price of the car is expensive", the word "car" is not vivid enough, so to make it become more vivid, we have to modify the word "car" into "the red Proton car" because it vividly elaborates the attributes of the car. In the third stage "postwriting", revising and presenting a clean copy of a descriptive composition were elaborated. According to Richards and Schmidt (2010), in this stage the writers check, revise, and rewrite what they have written. In the final /fifth session of this course, the teachers were asked to write a composition within the framework of Spencer's (ibid) model. And for the second time in this course, the teachers are asked to apply self-assessment technique in the classroom. In this section, the teachers were guided to check their compositions within the framework of Bartlett's and Spencer's models. The teachers were also guided to check elements such as using sensory details and descriptive words (i.e., look, sound, size, color, place, etc.), precise language, comparative structures, strong verbs, strong adjectives, transitional words, and spelling, while they were assessing their papers.

Interview Formation, and Dependability and Credibility Considerations

After the conduction of the training sessions for Iranian male and female EFL teachers, one form of One to One interview was designed (see app. A). Malone (2011) defined One to One Interview as "a type of interview in which more individual input, deeper emotional insights, and individual think, believe, feel, etc. are involved". To make the interview form informative enough, basic personal data and several open-ended questions were included and the dependability and credibility of the newly-developed interview form was checked. Noteworthy was that the content of the newly developed forms were first shown to two EFL experts, and they were asked to consider the dependability and credibility of the developed questions. 
Data Collection

After the preparation of the interview form, the researcher asked all of the Iranian male and female EFL teachers to participate in one to one interviews one after another within 20 minutes and the participants were fully informed about the interview conditions. In addition, the participants' answers were recorded (via a high quality voice recorder), archived, kept with high care. At last, the archived data were transcribed, checked, rechecked, and prepared for data analysis phase.

\section{Data Analysis}

In order to elicit the required factors which were needed for developing a Likert type questionnaire for EFL teachers, the researcher applied Ary et al (2019). three stages of qualitative data analysis for the analysis of the interview data: (1) familiarizing and organizing, (2) coding and reducing, and (3) interpreting and representing. Initially, the researcher tried to familiarize himself with the collected data obtained from the interviews by reading over and over the transcribed data. After familiarizing with the obtained data, a complete list of the data resources were provided and the files were organized in a variety of ways such as; interviewing sequence, gender categorization, themes/ factors of the interview, questions, etc. Secondly, through coding and reducing processes, the main themes /factors of the categorized data related to the attitudes of Iranian male and female EFL teachers towards self- and peer-assessment techniques in descriptive writing were identified.

Using constant comparative method of analysis by (Ary et al., 2019) and Stratuss and Corbin's (1998) model of data codification the collected data were codified. To codify the obtained data, all of the words, phrases, sentences, themes and patterns, which were highlighted for data representation and interpretation were elicited. Thereafter, frequencies and percentages of the codified data were descriptively and analytically reported. Furthermore, the researcher recruited two Iranian EFL experts /coders (i.e., a person who codifies the research data based on the pre-specified themes) to check and recheck the obtained data of the interviews which were calculated by the researcher. After rechecking means of the themes the main ones were selected.

\section{Strand Two: Quantitative}

\section{Settings and Population}

In selecting the research participants of this strand, one procedure of non-random or non-probability technique that is purposeful sampling procedure by Best and Kahan (2006) was used. Here, the investigator selected the same 20 male and 20 female EFL teachers among the participants who took part in the stated training course.

4.3.2 Questionnaire Development and Reliability and Validity Considerations

The researcher selected the identified themes and factors from the EFL teachers' interviews in the qualitative strand, and based on them a 16 items questionnaire for eliciting EFL teachers' attitudes towards the course was developed. Moreover, the reliability of the questionnaires were considered as follows:
The results of the reliability revealed that Cronbach's Alpha of the newly-developed questionnaire was .853. The obtained data showed that the developed questionnaire was reliable because the obtained Cronbach's Alpha was above .70. Theme analysis also indicated that the statistical internal consistency of the themes or criteria, forming the scale were $.907, .887, .789, .874$, and .783 . It can be concluded that the themes were acceptable, too.

\section{Data Collection and Procedures}

After developing the questionnaire, the researcher administered them among 40 Iranian male and female EFL teachers and tried to elicit and discover the attitudinal differences between male and female attitudes towards selfand peer-assessment in descriptive writing within at least 20 minutes.

\section{Data Analysis}

To analyze the data of the study, the investigator used exploratory factor analysis by Pallant, J. (2013) for analyzing the obtained data, considering the interrelationships among the research variables, and calculating reliability and validity of the questionnaire. After the administration of the questionnaires, researcher applied IBM SPSS version 22 i.e., and used One Way Multi-Analysis of Variance by Pallant, J (2013) for eliciting Iranian male and female EFL teachers' attitudes towards the course, too

\section{Results}

\section{Qualitative Strand}

Qualitative Data Analysis of Iranian Male and female EFL Teachers' Attitudes towards Self-and Peer-assessment in Descriptive Writing

From the taken course, administered interviews, codified data, and audit trails' comments the following themes namely cooperation, positivity, independence, practice, strengths and weaknesses were recognized for developing a valid and reliable scale for assessing Iranian male and female EFL teachers' attitudes in descriptive writing (See Table below).

Table (1) Hypothetical conceptualization of EFL teachers' themes of self-and peer-assessment in descriptive writing

\begin{tabular}{l}
\hline Components (Themes) of EFL Teachers' \\
Questionnaire \\
\hline Cooperation:
\end{tabular}

Cooperation:

(i.e., it is the extent to which EFL teachers have tendency to work together towards a common goal).

\section{Cooperation: \\ (i.e., it is the extent to which EFL teachers have tendency to work together towards a common goal).}

\section{Positivity:}

(i.e., it is a psychological state that causes EFL teachers to consider the techniques as helpful ones in writing a better composition).

\section{Independence:}

(i.e., it is the amount in which EFL teachers can freely apply the techniques in their own classes).

\section{Practice:}

21 (i.e., it a way of applying the techniques in an expected way). 


\begin{abstract}
Strengths and weaknesses:
(i.e., how well EFL learners are able to refer to positive and negative aspects of their own or peers' compositions).

As the table shown, the selected components were appropriate for developing the required questionnaire and the EFL teachers' attitudes towards the administered course were positive at the first sight but much more practices were recommended.
\end{abstract}

Quantitative Strand

Conduction of Exploratory Factor Analysis for EFL Teachers

The results of Exploratory Factor Analysis were as follows: (1) the developed items of the EFL teachers' questionnaire were suitable, (2) the correlation coefficient between the factors and the items were high and appropriate. To inform the reader of this article, highlighted details are presented in tabulated forms (See tables 2-6 below).

Table (2) Descriptive representations of the EFL teachers' questionnaires

\begin{tabular}{|c|c|c|c|c|c|c|c|c|c|}
\hline & $\mathrm{N}$ & $\begin{array}{c}\text { Minim } \\
\text { um }\end{array}$ & $\begin{array}{l}\text { Maxi } \\
\text { mum }\end{array}$ & $\begin{array}{c}\text { Mea } \\
\mathrm{n}\end{array}$ & $\begin{array}{c}\text { Std. } \\
\text { Deviat } \\
\text { ion } \\
\end{array}$ & \multicolumn{2}{|c|}{ Skewness } & \multicolumn{2}{|c|}{ Kurtosis } \\
\hline & $\begin{array}{l}\text { Stati } \\
\text { stic }\end{array}$ & $\begin{array}{c}\text { Statisti } \\
\text { c }\end{array}$ & $\begin{array}{l}\text { Statist } \\
\text { ic }\end{array}$ & $\begin{array}{l}\text { Stati } \\
\text { stic }\end{array}$ & $\begin{array}{c}\text { Statisti } \\
\text { c }\end{array}$ & $\begin{array}{l}\text { Stati } \\
\text { stic }\end{array}$ & $\begin{array}{c}\text { Std. } \\
\text { Erro } \\
r\end{array}$ & $\begin{array}{l}\text { Stat } \\
\text { istic }\end{array}$ & $\begin{array}{c}\text { Std. } \\
\text { Erro } \\
\text { r }\end{array}$ \\
\hline TI8 & 40 & 3 & 5 & 4.73 & .506 & $\begin{array}{c}- \\
1.65 \\
7\end{array}$ & .374 & $\begin{array}{c}2.0 \\
18\end{array}$ & .733 \\
\hline TI9 & 40 & 4 & 5 & 4.70 & .464 & $\begin{array}{c}- \\
.907\end{array}$ & .374 & $\begin{array}{c}- \\
1.2 \\
42\end{array}$ & .733 \\
\hline TI11 & 40 & 4 & 5 & 4.68 & .474 & $\begin{array}{c}- \\
.777\end{array}$ & .374 & $\begin{array}{c}- \\
1.4 \\
73\end{array}$ & .733 \\
\hline TI10 & 40 & 4 & 5 & 4.68 & .474 & $\begin{array}{c}- \\
.777\end{array}$ & .374 & $\begin{array}{c}- \\
1.4 \\
73\end{array}$ & .733 \\
\hline TI2 & 40 & 4 & 5 & 4.65 & .483 & $\begin{array}{c}- \\
.654\end{array}$ & .374 & $\begin{array}{c}- \\
1.6 \\
58\end{array}$ & .733 \\
\hline TI7 & 40 & 3 & 5 & 4.65 & .533 & $\begin{array}{c}- \\
1.17 \\
9\end{array}$ & .374 & $\begin{array}{c}.43 \\
2\end{array}$ & .733 \\
\hline TI5 & 40 & 3 & 5 & 4.63 & .540 & $\begin{array}{c}- \\
1.04 \\
4\end{array}$ & .374 & $\begin{array}{c}.08 \\
4\end{array}$ & .733 \\
\hline TI4 & 40 & 4 & 5 & 4.63 & .490 & $\begin{array}{c}- \\
.537\end{array}$ & .374 & $\begin{array}{c}- \\
1.8 \\
05\end{array}$ & .733 \\
\hline TI6 & 40 & 3 & 5 & 4.60 & .545 &. & .374 & $\begin{array}{c}- \\
.20 \\
0\end{array}$ & .733 \\
\hline TI13 & 40 & 4 & 5 & 4.60 & .496 & $\begin{array}{c}- \\
.424\end{array}$ & .374 & $\begin{array}{c}- \\
1.9 \\
19\end{array}$ & .733 \\
\hline TI3 & 40 & 4 & 5 & 4.60 & .496 & $\begin{array}{c}- \\
.424\end{array}$ & .374 & $\begin{array}{c}- \\
1.9 \\
19\end{array}$ & .733 \\
\hline TI1 & 40 & 1 & 5 & 4.48 & .751 & $\begin{array}{c}- \\
2.59 \\
1\end{array}$ & .374 & $\begin{array}{l}10 . \\
730\end{array}$ & .733 \\
\hline TI12 & 40 & 4 & 5 & 4.43 & .501 & .315 & .374 & $\begin{array}{c}- \\
2.0 \\
03\end{array}$ & .733 \\
\hline TI17 & 40 & 2 & 5 & 4.20 & .758 & $\begin{array}{c}- \\
.729\end{array}$ & .374 & $\begin{array}{c}.37 \\
8\end{array}$ & .733 \\
\hline
\end{tabular}

\begin{tabular}{|c|c|c|c|c|c|c|c|c|c|}
\hline TI14 & 40 & 1 & 5 & 4.15 & .949 & $\begin{array}{c}- \\
1.45 \\
2\end{array}$ & .374 & $\begin{array}{l}2.4 \\
70\end{array}$ & .733 \\
\hline TI16 & 40 & 2 & 5 & 4.15 & .736 & - & .374 & $\begin{array}{c}.52 \\
6\end{array}$ & .733 \\
\hline TI15 & 40 & 1 & 5 & $\begin{array}{c}2.72 \\
*\end{array}$ & .960 & .412 & .374 & $\begin{array}{c}.17 \\
5\end{array}$ & .733 \\
\hline $\begin{array}{l}\text { Valid } \\
\mathrm{N}(\text { listw } \\
\text { ise) }\end{array}$ & 40 & & & & & & & & \\
\hline
\end{tabular}

The descriptive statistics indicates the total number of EFL teachers, items, means, standard deviations, etc. The given statistics in Table 2 firstly showed that $100 \%$ of the research participants replied to the questionnaires. Secondly, means of the answered items represented the fact that most of them except for item No. 15 were above 4 which gave rich data about the suitability of the other items. Moreover, negative statistics of gave information about the appropriacy of the items.

Table (3) Kaiser-Meyer-Olkin Measure of sampling adequacy (KMO) and Bartlett's Test of Sphericity (BTS)

\begin{tabular}{lcr}
\hline \hline Kaiser-Meyer-Olkin Measure of Sampling & $\mathbf{. 6 8 3}$ \\
$\begin{array}{l}\text { Adequacy. } \\
\text { Bartlett's Test of }\end{array}$ & Approx. Chi-Square & 87.44 \\
Sphericity & & 0 \\
& Df & 10 \\
& Sig. & $\mathbf{. 0 0 2}$ \\
\hline \hline
\end{tabular}

Table 3 gave information about the suitability of the data through two tests: KMO and BTS. The obtained statistics related to KMO was .683 which was above the assigned statistics (.6) by Pallant (2013) and also Bartlett's Test of Sphericity's indicated the significance of the data $(p>.002)$. In summary, the obtained statistics related to the tests confirmed the suitability of the developed questionnaire.

Table (4) Total variance explained

\begin{tabular}{|c|c|c|c|c|c|c|c|c|c|}
\hline \multirow[b]{2}{*}{$\begin{array}{c}\text { Com } \\
\text { pone } \\
\text { nt }\end{array}$} & \multicolumn{3}{|c|}{ Initial Eigenvalues } & \multicolumn{3}{|c|}{$\begin{array}{c}\text { Extraction Sums of } \\
\text { Squared Loadings }\end{array}$} & \multicolumn{3}{|c|}{$\begin{array}{l}\text { Rotation Sums of } \\
\text { Squared Loadings }\end{array}$} \\
\hline & Total & $\begin{array}{l}\% \text { of } \\
\text { Varian } \\
\text { ce }\end{array}$ & $\begin{array}{l}\text { Cumul } \\
\text { ative } \\
\%\end{array}$ & Total & $\begin{array}{l}\% \text { of } \\
\text { Vari } \\
\text { ance }\end{array}$ & $\begin{array}{l}\text { Cumulati } \\
\text { ve } \%\end{array}$ & $\begin{array}{l}\text { Tota } \\
1\end{array}$ & $\begin{array}{l}\% \text { of } \\
\text { Varia } \\
\text { nce }\end{array}$ & $\begin{array}{l}\text { Cumula } \\
\text { tive } \%\end{array}$ \\
\hline 1 & $\begin{array}{l}1.269 \\
*\end{array}$ & 25.380 & 25.38 & 1.26 & 25.3 & 25.380 & \begin{tabular}{|l|}
1.0 \\
$x$
\end{tabular} & $\begin{array}{l}20.00 \\
5\end{array}$ & 20.005 \\
\hline 2 & $\begin{array}{l}1.194 \\
*\end{array}$ & 23.871 & 49.25 & 1.19 & 23.8 & 49.250 & 1.0 & $\begin{array}{l}20.00 \\
2\end{array}$ & 40.007 \\
\hline 3 & ${ }_{*}^{1.102}$ & 22.039 & 71.28 & 1.10 & 22.0 & 71.289 & 1.0 & $\begin{array}{l}20.00 \\
0\end{array}$ & 60.007 \\
\hline 4 & $\begin{array}{l}1.012 \\
*\end{array}$ & 15.648 & 86.93 & 1.01 & 15.6 & 86.937 & 1.0 & $\begin{array}{l}19.99 \\
8\end{array}$ & 80.006 \\
\hline 5 & $\begin{array}{l}1.003 \\
*\end{array}$ & 13.063 & 100.0 & 1.00 & 13.0 & 100.000 & 1.0 & $\begin{array}{l}19.99 \\
4\end{array}$ & 100.000 \\
\hline
\end{tabular}

Note. Asterisk marks showed that factors No.1 to 5 were suitable.

Table 4 illustrated the initial eigenvalues, or the amount of variance of the original variables for each component. It also represented that all of the components or factors had eigenvalues exceeded the value of 1 including 1.269, 1.194, 1.102, and 1.012. The components explained a total of $100.000 \%$ of the variance. The second section of the table gave data about the extraction sums of squared loadings 
DOI: $10.21608 /$ ihites.2021.82147.1045

without rotation. Accordingly, all of the components numbers 1 to 5 that had values more than 1 were considered suitable for designing EFL teachers' questionnaire.

Table (5) Component matrix

\begin{tabular}{lccccc}
\hline \hline & \multicolumn{5}{c}{ Component } \\
\cline { 2 - 6 } & $\mathbf{1}$ & $\mathbf{2}$ & $\mathbf{3}$ & $\mathbf{4}$ & $\mathbf{5}$ \\
\hline IN & .754 & & .602 & .688 \\
PR & .692 & .802 & & .717 \\
COPO & & .699 & .720 & .407 & .584 \\
STWE & .502 & .419 & & .611 & \\
TA & & & .766 & .591 & \\
\hline \hline
\end{tabular}

Table 5 represented that correlation of the most of the factors were high and positioned between .37 to .80 . According to the table, factors such as independence, practice, cooperation and positivity, teacher-assessment, and strengths and weaknesses were appropriate for developing a suitable scale for assessing EFL teachers' attitudes towards self- and peer-assessment in descriptive writing.

Table (6) Rotated component matrix

\begin{tabular}{lccccc}
\hline \hline & & \multicolumn{3}{c}{ Component } \\
& $\mathbf{1}$ & $\mathbf{2}$ & $\mathbf{3}$ & $\mathbf{4}$ & $\mathbf{5}$ \\
COPO & .903 & & & & \\
TA & & .936 & & & \\
STWE & & & .834 & & \\
IN & & & & .889 & \\
PR & & & & & .948 \\
\hline \hline
\end{tabular}

Table 6 indicated that high percentages of the EFL teachers' questionnaires were highly correlated and these supported the suitability of the suggested factors such as independence, cooperation and positivity, practice, strengths and weaknesses, and teacher-assessment

\section{Conduction of One-Way MANOVA for EFL Teachers}

The results of one-way MANOVA for eliciting EFL teachers' attitudes were as follows; (1) the obtained data were normal and no outliers were detected, (2) the results showed that both of the Iranian male and female EFL teachers had positive attitudes towards the course, (3) there was a statistical significant difference between Iranian male and female EFL teachers' attitudes towards the course and males' means were larger than females' ones. The given information in Tables 7-13 justify the stated results in numerical forms

Table (7) Descriptive statistics

\begin{tabular}{llccc}
\hline & SEX & Mean & $\begin{array}{c}\text { Std. } \\
\text { Deviation }\end{array}$ & N \\
\hline COPO & Male & 18.40 & 1.142 & 20 \\
& Female & 18.30 & .979 & 20 \\
& Total & 18.35 & 1.051 & 40 \\
\hline IN & Male & 9.30 & .733 & 20 \\
\hline
\end{tabular}

\begin{tabular}{lllll} 
& Female & 9.15 & 1.089 & 20 \\
& Total & 9.22 & .920 & 40 \\
\hline PR & Male & 19.00 & 1.026 & 20 \\
& Female & 18.50 & 1.277 & 20 \\
& Total & 18.75 & 1.171 & 40 \\
\hline TA & Male & 12.95 & 1.234 & 20 \\
& Female & 12.05 & 1.669 & 20 \\
& Total & 12.50 & 1.519 & 40 \\
\hline STWE & Male & 13.75 & .786 & 20 \\
& Female & 13.65 & .933 & 20 \\
& Total & 13.70 & .853 & 40 \\
\hline \hline
\end{tabular}

This Table represented the descriptive statistics such as means, standard deviations, and numbers about Iranian male and female EFL teachers before the conduction of One-Way MANOVA. In the table, no missing values were found because the data were entered truly

Table (8) Multivariate tests

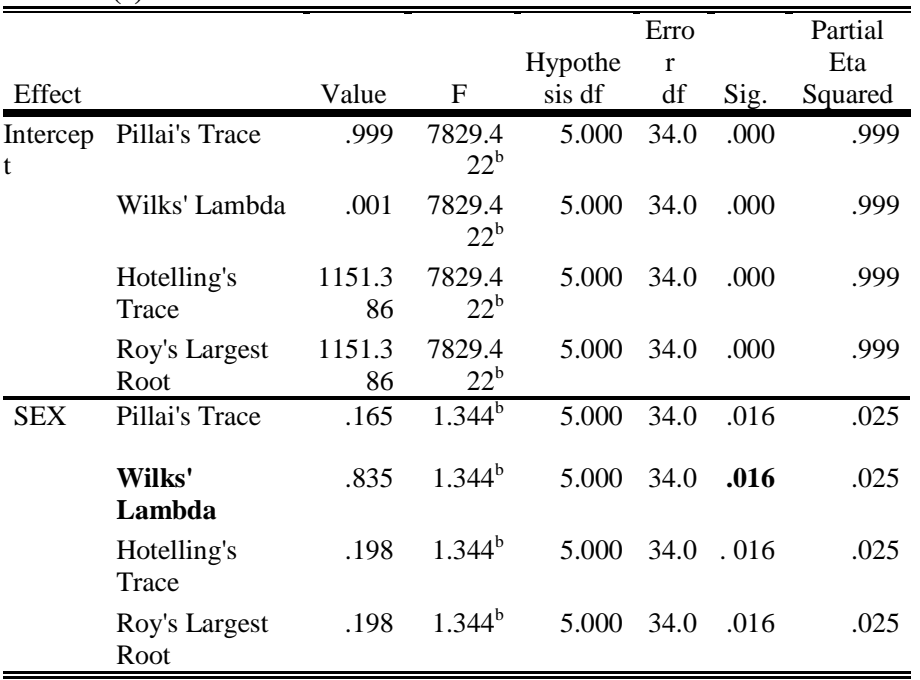

Table 8 illustrated that there was a statistical significant difference between Iranian male and female EFL teachers' attitudes towards the course. A clear look at Wilks' Lambda in the Sex Row confirmed the fact that the obtained Sig. was statistically significant $(.016<.05)$. So, it can be concluded that male and female means of the research participants were different

Table (9) Tests of between-subjects effects

\begin{tabular}{llrrrrrr}
\hline \hline Source & $\begin{array}{l}\text { Dependent } \\
\text { Variable }\end{array}$ & $\begin{array}{l}\text { Type III } \\
\text { Sum of } \\
\text { Squares }\end{array}$ & Df & $\begin{array}{c}\text { Mean } \\
\text { Square }\end{array}$ & F & Sig. & $\begin{array}{c}\text { Partial } \\
\text { Squared }\end{array}$ \\
\hline SEX & COPO & .100 & 1 & .100 & .088 & $\mathbf{. 0 0 3}$ & .002 \\
& IN & .225 & 1 & .225 & .261 & $\mathbf{. 0 1 2}$ & .007 \\
& PR & 2.500 & 1 & 2.500 & 1.863 & $\mathbf{. 0 2 0}$ & .047 \\
& TA & 8.100 & 1 & 8.100 & 3.758 & $\mathbf{. 0 0 0}$ & .050 \\
& STWE & .100 & 1 & .100 & .134 & $\mathbf{. 0 1 6}$ & .004 \\
\hline Error & COPO & 43.000 & 38 & 1.132 & & &
\end{tabular}




\begin{tabular}{|c|c|c|c|c|}
\hline & IN & 32.750 & 38 & .862 \\
\hline & PR & 51.000 & 38 & 1.342 \\
\hline & TA & 81.900 & 38 & 2.155 \\
\hline & STWE & 28.300 & 38 & .745 \\
\hline \multirow[t]{5}{*}{ Total } & COPO & 13512.0 & 40 & \\
\hline & IN & 3437.00 & 40 & \\
\hline & PR & 14116.0 & 40 & \\
\hline & TA & 6340.00 & 40 & \\
\hline & STWE & 7536.00 & 40 & \\
\hline \multirow{5}{*}{$\begin{array}{l}\text { Corrected } \\
\text { Total }\end{array}$} & $\mathrm{COPO}$ & 43.100 & 39 & \\
\hline & IN & 32.975 & 39 & \\
\hline & PR & 53.500 & 39 & \\
\hline & TA & 90.000 & 39 & \\
\hline & STWE & 28.400 & 39 & \\
\hline
\end{tabular}

Table 9 of Between-Subjects Effects showed that the obtained Sig. levels were smaller than .05 in all of the confirmed factors. Based on the obtained statistics, it can be concluded that male and female means were statistically different, and the subjects of this study had positive attitudes towards the course Table (10) Descriptive statistics

\begin{tabular}{|c|c|c|c|c|c|}
\hline \multirow[b]{2}{*}{$\begin{array}{l}\text { Dependent } \\
\text { Variable }\end{array}$} & \multirow[b]{2}{*}{ SEX } & \multirow[b]{2}{*}{ Mean } & \multirow[b]{2}{*}{$\begin{array}{c}\text { Std. } \\
\text { Error }\end{array}$} & \multicolumn{2}{|c|}{$\begin{array}{l}95 \% \text { Confidence } \\
\text { Interval }\end{array}$} \\
\hline & & & & $\begin{array}{l}\text { Lower } \\
\text { Bound }\end{array}$ & $\begin{array}{l}\text { Upper } \\
\text { Bound }\end{array}$ \\
\hline \multirow[t]{2}{*}{ COPO } & Male & 18.400 & .238 & 17.918 & 18.882 \\
\hline & Female & 18.300 & .238 & 17.818 & 18.782 \\
\hline \multirow[t]{2}{*}{ IN } & Male & 9.300 & .208 & 8.880 & 9.720 \\
\hline & Female & 9.150 & .208 & 8.730 & 9.570 \\
\hline \multirow[t]{2}{*}{$\overline{\mathbf{P R}}$} & Male & 19.000 & .259 & 18.476 & 19.524 \\
\hline & Female & 18.500 & .259 & 17.976 & 19.024 \\
\hline \multirow[t]{2}{*}{$\overline{\text { TA }}$} & Male & 12.950 & .328 & 12.285 & 13.615 \\
\hline & Female & 12.050 & .328 & 11.385 & 12.715 \\
\hline \multirow[t]{2}{*}{ STWE } & Male & 13.750 & .193 & 13.359 & 14.141 \\
\hline & Female & 13.650 & .193 & 13.259 & 14.041 \\
\hline
\end{tabular}

Table 10 gave information about each factor and the participants' means, in sequence. A concise look at the mean differences among the factors showed that males' means were larger than females' means. Consequently, it can be concluded that males' and females' attitudes towards the course were different Results of the proposed research questions in the qualitative and quantitative strands

RQ NO. 1: What are Iranian male and female EFL teachers' attitudes towards self-and peer-assessment in descriptive writing?

Based on the obtained information in the first section of the qualitative strand both Iranian male and female EFL teachers had positive attitudes towards self-and peer-assessment in descriptive writing for the coming reasons: The first proof was that from the start to the end of the course all of the research participants were motivated to cooperate in training sessions, regularly. The second reason was pertained to the EFL teachers' knowledge in which their knowledge of self-and peerassessment in descriptive writing were greatly increased in comparison with their knowledge prior to the course conduction. At the end of the course roughly one-hundred of the male and female EFL teachers were acquaintance with the course. In addition, the trained Iranian male and female EFL teachers voluntarily declared to administer the course in their own classes. The last one was related to the elicited themes (i.e., cooperation, positivity, independence, practice, strengths and weaknesses) from the interviews to develop a questionnaire for EFL teachers. From the recommended themes, it can be concluded that both Iranian male and female EFL teachers had positive attitudes towards the course.

RQ NO.2: Do the identified factors/ variables predict Iranian male and female EFL teachers' attitudes towards self-and peer-assessment in descriptive writing?

Based on the obtained statistics in Tables 2, 3, 4, 5, and 6 all of the recognized factors highly predicted Iranian male and female EFL teachers' attitudes towards the course, in general. Table 3 represented the fact that the recommended components (practice, teacher-assessment, strengths and weaknesses, cooperation, and positivity) were suitable to elicit the research participants' attitudes towards the course. Table 4 showed that variance of all of the factors were above .30 which gave data about the fitness of the factors. Moreover, the data in Tables 5 and 6 showed that all of the factors were suitable for eliciting male and female EFL teachers' attitudes towards the course because all of them had high correlation coefficient.

RO NO. 3: To what extent, is there a statistically significant difference between Iranian male and female EFL teachers' attitudes in terms of the factors identified?

Based on the statistics obtained from one-way MANOVA administration in Tables 7 - 10 it can be concluded that there was a statistical significant difference between Iranian male EFL teachers' attitudes towards the course for the following reasons: The first proof was provided in Table 7 . The obtained data in the table showed that male EFL teachers had higher means than female ones among the identified factors i.e., cooperation, independence, practice, teacher-assessment, and strengths and weaknesses. The second proof was related to Table 8 in which the results of Wilks' Lambda represented that there was a statistical significant difference between Iranian male and female EFL teachers towards the course. The next proofs were provided in Tables 9 and 10 in which male and female EFL teachers' means were not only statistically significant but also differed greatly from each other. From the stated proofs, it can be concluded that both of the male and female EFL teachers had positive attitudes towards the course and the only difference backed to mean differences among them.

\section{Discussion}

This section of this exploratory sequential mixed methods study discusses the findings of qualitative and quantitative strands, consecutively. 
Qualitative Strand: For the analysis of the EFL teachers' confirmed themes ("practice", "strengths and weaknesses", "independence", "cooperation and positivity", and "teacherassessment"), we concluded that they were pivotal for the following reasons: (1) motivated EFL teachers to use the techniques and suggested models as much as possible in their own classes to improve EFL learners' descriptive writing skill ; (2) assisted EFL teachers in finding their colleagues' strengths and weaknesses in writing a better composition; (3) encouraged EFL teachers to provide a cooperative class for EFL learners to work together and also made them positive in accomplishing the tasks. Moreover, the findings of this strand confirmed the usefulness of the elicited factors for developing the questionnaire for EFL teachers.

Quantitative Strand: The results of exploratory factor analysis test for EFL teachers represented that the confirmed factors for developing the questionnaire were highly appropriate to elicit the participants' attitudes towards the course. The results of one-way MANOVA tests for EFL teachers also confirmed that the research participants had positive attitudes towards the self-and peer-assessment in descriptive writing. In comparison with the findings of the previous studies, it can be concluded that parallel implementation of the techniques changed the attitudes of Iranian male and female EFL teachers positively. In addition, the obtained results showed that the given treatment improved the research participants' descriptive writing skill.

\section{Implications}

The findings of this study strengthened the review of literature from two standpoints: theoretical and pedagogical.

The results of the qualitative and quantitative strands theoretically may extend the literature on assessment in writing in the following ways: (1) extended need of knowledge about mixed methods design and confirmed the comprehensive outcomes of exploratory mixed methods design; (2) validated cognitive and social branches of constructivism school by Jean Piaget and Lev Vygotsky on self-and peer-assessment in assessing individuals' attitudes towards the course;(3) developed metacognitive and cognitive views of writing in focusing on selfand peer-assessment in descriptive writing; (4) empowered expressivist view of writing in highlighting the concepts of creativity and discovery in the process of writing.

The following pedagogical implications are those that have occurred to the researcher; perhaps specialists can reach at safer and sounder ones.

1. EFL teachers' knowledge of self-and peerassessment should be examined, and they should be informed about the importance of descriptive writing skill.

2. EFL teachers should be encouraged to write at least three unified descriptive tasks and they should be asked to apply self-and peerassessment model of two stars and a wish on their own compositions.

3. EFL teachers should be acquaintance with three main stages of writing, "pre", "while", and "post".
4. EFL teachers should be familiarized with Spencer (2005) model of descriptive writing, and they should be informed that this activity helps them to write a better composition.

5. EFL teachers should be informed to follow the provided models.

6. The researcher's made questionnaire for EFL teachers should be used after the course to elicit their attitudes towards the course.

\section{References}

[1] Khatib, M. and Mirzaii, M. (2016). Enhancing Iranian EFL Learners' Descriptive Writing Skill through Genre-Based Instruction and Metalinguistic Feedback. Journal of Teaching Language skills: 35(2), pp.39-68.

[2] Richards, J. C., \& Schmidt, R. (2010). Dictionary of Language Teaching and Applied Linguistics (4th ed.). London: Pearson Education

[3] Suriyanti, S. \& Yaacob, A. (2016). Exploring Teacher Strategies in Teaching Descriptive Writing in Indonesia. Malaysian Journal of Learning and Instruction: 13(2) p. 71-95.

[4] Meyers, A. (2006). Writing with confidence: writing effective sentences and paragraphs (8th Ed).

[5] Hyland, K. (2016). Teaching and Researching Writing: Applied Linguistics in Action (3rd ed.).New York: Routledge.

[6] Pallant, J. (2013). A Step by Step Guide to Data Analysis Using IBM SPSS: SPSS Survival Manual (5th ed). New York, NY: Open University Press.

[7] Kongevold, S. (2014). Second Language Teaching Methods in two Different Countries: A Case Study. Master's Thesis, University of Stavanger.

[8] Creswell, J.W. (2014). Research Design: Qualitative, Quantitative, and Mixed Methods Approaches. Sage Publications, Inc

[9] Brown, H. D. (2004). Language Assessment: Principles and Classroom Practices. New York. Pearson Education, Inc.

[10] Ary, D., Jacobs, L.C., Sorensen, C., \& Walker, D.A. (2014). Introduction to Research in Education (9th ed). United States of America: Wadsworth and Cengage Learning

[11] Creswell, J.W. \& Plano Clark, V.L. (2017). Designing and Conducting Mixed Methods Research. Sage Publications, Inc

[12] Farhady, H. (2006). Twenty Five Years of Living with Applied Linguistics: Collection of Articles. Tehran: Rahnama

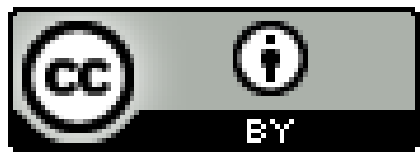

